\title{
Coastal People Activity on Mangrove Forest Rehabilitation in Mahakam Estuary
}

\author{
Adriyani Samad ${ }^{1)}$, Azis Nur Bambang2) and Norma Afiati ${ }^{2)}$ \\ 1) Department of Agriculture Developing, Plantation and Forestry Samarinda, Jl. Biola Samarinda, East Kalimantan \\ 2) Fisheries and Marine Science Faculty of Diponegoro University, Jl. Prof. Soedarto, SH. Kampus UNDIP Tembalang \\ Semarang 50275
}

Email: adrianisamad@gmail.com

\section{Paper history:}

Submission : March 1, 2013

Correction recieved: March 14, 2013

Accepted : March 15, 2013

doi: 10.12777/ijwr.v3.i1.p34

\begin{abstract}
Present condition shows that balance and environmental sustainability of mangrove forests in Mahakam Estuary (Delta Mahakam) area has changed which can result negative effect on people activity of coastal communities. Destruction of mangrove forest is caused by intervention and rapid population growth, especially in coastal areas, which result land use change and excessive utilization of natural resources. This condition can lead to degradation of mangrove forest. In order to rehabilitate mangrove forest, active participation from coastal community is needed. In this regard, this research was carried out in order to assess the perception and participation as well as strategies that can be implemented to improve community participation on mangrove forest rehabilitation. The research was conducted in five villages (Saliki, Salo Palai, Muara Badak Ulu, Muara Badak Ilir and Tanjung Limau), Formulation strategies was carried out using SWOT (Strengths, Weaknesses, Opportunities, Threats) method through Focus Group Discussion which combined with Analytical Hierarchy Process to determine the priority of alternative strategies and policies on mangrove forest rehabilitation. The analysis shows that social factor which influences community's participation towards the rehabilitation of coastal mangrove forest is perception variable. Strategy which is expected to improve community participation in mangrove rehabilitation activities is carried out by optimizing the strength factor and take advantage from the opportunities (Strengths Opportunities Quadrant Strategy). Based on formulated strategies, it can be obtained four priority alternatives which can be implemented to improve coastal community participation, i.e.: 1) Development of rural participatory for mangrove nursery; 2) Generates positive perception on the strengthening coastal communities about the advantage and functions of mangrove forests; 3) control upon re-vegetation and restoration of coastal areas resources which suffer from degradation and deforestation; and 4) Accelerate the establishment of Guidance Unit Team and Technical Guidance Unit of Mangrove Forest.
\end{abstract}

Keywords - Coastal, Forest, Activity, Mangrove and Rehabilitation

\section{INTRODUCTION}

Mahakam estuary (Delta Mahakam) is a coastal area with specific geology and ecology which is characterized by geological condition of delta and estuarine which in turn creates ideal environment for mangrove growth. In economical point of view, mangrove has long-term economic value (characterized by low discount rate) while oil and gas have short term economic value (characterized by high discount rate) (Bengen et al., 2003; Hopley 1999; Voss and Frithjof, 1983). Mahakam estuary consists of four sub districts i.e. Anggana, Muara Jawa, Muara Badak, and Samboja (Syamsuri, 2001). Similar with others coastal community area which have open community characteristic, the community of Mahakam estuary consists of local and migrant resident inhabitant particularly Bugis ethnic from South Sulawesi (Bourgeois et al., 2002).

Definition delta or estuarine include three aspects such as fauna composition, estuarine vegetation and estuarine plankton. Estuary is defined as partly enclosed coastal area with connection to the open sea which is very affected by the intensity of tidal water mixes with saline and water runoff. The main physical and biological characteristic is unique not transition (Wibowo et al., 1996; Clark and John, 1974). 
Land use changes of mangrove areas into fishpond have negative effect on ecological and biophysics processes, such as erosion (coastal abrasion); disappearance of coastal green belt which serves as a damper and barrier against waves, strong current and storm; declined water quality; reduced biodiversity; disappearance of habitat, spawning ground, nursery ground and feeding ground for various species of fishes, shrimps and others sea biota (Bengen et al., 2003; Dutrieux, 2001).

Unplanned utilization of Mahakam estuary area increases land use changes from mangrove into fishponds. In this 20 years, 80.000 ha mangrove area has changed in which 67.000 ha has converted into fishpond area (Bengen et al., 2003; Dutrieux, 2001).

Exploitation under complex social and economic circumstance has charged coastal area with heavier responsibilities which in turn generates negative impact on degradation and deforestation of Mahakam estuary area. Along with the increased population, the land use plan and governance arrangements should be implemented in cross-sector and integrated management based on environmental balance aspects (Sidik, 2008).

Development on strategies and rehabilitation policies of mangrove forest needs involvement and participation of surrounding communities which live in Mahakam estuary of coastal area in order to carry out rehabilitation program. The purpose of this research is to gain people activity information of coastal community to maintenance environmental sustainability of mangrove forests in Mahakam Estuary.

\section{MATERIAL AND METHOD}

The study was conducted in Mahakam estuary, East Kalimantan Province, Indonesia. The area of Mahakam estuary consists of big and small is estuary lands which gather at the mouth of Mahakam River. Geographically, the area is located on $170^{\circ} 15^{\prime} 0^{\prime \prime}-170^{\circ} 36^{\prime} 46.2^{\prime \prime}$ east longitude and $00^{\circ} 20^{\prime} 48^{\prime \prime}-00^{\circ} 48^{\prime} 49.8^{\prime \prime}$ south latitude. The method of this research was descriptive study; determine factors which affect the people activity on participation of coastal community in regard with rehabilitation effort of mangrove forest. SWOT (Strengths, Weaknesses, Opportunities, Threats) analysis was applied in order to determine the strength, weaknesses, opportunities and threats which was combined with Analytical Hierarchy Process (Saaty, 1993; Mayulu, 2012; Asikin et al., 2012).

There were two components which analysing on this research i.e.: 1) people knowledge about mangrove forest rehabilitation; and 2) people involvement on mangrove forest rehabilitation.

Primary data was collected which included: 1) Coastal community perception on mangrove forest use and function, mangrove felling trees without permission, legal sanction to illegal loggers, rehabilitation and conservation, extension, land use supervision and control; and 2) Coastal community participation on mangrove forest rehabilitation program that put them into planning, nursery, conservation, monitoring and evaluation as well as securing and protecting forest area. The study was conducted in Mahakam estuary, East Kalimantan Province, Indonesia. The area of Mahakam estuary consists of big and small is estuary lands which gather at the mouth of Mahakam River. Geographically, the area is located on $170^{\circ} 15^{\prime} 0^{\prime \prime}-170^{\circ} 36^{\prime} 46.2^{\prime \prime}$ east longitude and $00^{\circ} 20^{\prime} 48^{\prime \prime}$ $00^{\circ} 48^{\prime} 49.8^{\prime \prime}$ south latitude. The method of this research was descriptive study; determine factors which affect the people activity on participation of coastal community in regard with rehabilitation effort of mangrove forest. SWOT (Strengths, Weaknesses, Opportunities, Threats) analysis was applied in order to determine the strength, weaknesses, opportunities and threats which was combined with Analytical Hierarchy Process (Saaty, 1993; Mayulu, 2012; Asikin et al., 2012).

There were two components which analysing on this research i.e.: 1) people knowledge about mangrove forest rehabilitation; and 2) people involvement on mangrove forest rehabilitation.

Primary data was collected which included: 1) Coastal community perception on mangrove forest use and function, mangrove felling trees without permission, legal sanction to illegal loggers, rehabilitation and conservation, extension, land use supervision and control; and 2) Coastal community participation on mangrove forest rehabilitation program that put them into planning, nursery, conservation, monitoring and evaluation as well as securing and protecting forest area.

\section{RESULT AND DISCUSSION}

The total district area is approximately $27.263 .10 \mathrm{~km}^{2}$ lies between 115' '26'28'-117' '36'43" east longitude and $01^{\circ} 28^{\prime} 21^{\prime \prime}-01^{\circ} 08^{\prime} 06^{\prime \prime}$ south latitude. Muara Badak is a district located in coastal areas, $89 \mathrm{~km}$ from capital city of Kutai district, Tenggarong. It has $939.09 \mathrm{~km}^{2}(3.44 \%)$ area which located between $117^{\circ} 07^{\prime} 00^{\prime \prime}-117^{\circ} 32^{\prime} 00^{\prime \prime}$ east longitude and $0^{\circ} 11^{\prime} 00^{\prime \prime}-0^{\circ} 31^{\prime} 00^{\prime \prime}$ south latitude. The slope topography ranges from flat to gently sloping which is found in some parts of the coastal area.

Economic development under mangrove forest uses is growing fast in Muara Badak which part of Mahakam estuary area. This condition leads to significant contribution on increasing economic life and welfare of coastal community particularly for workers, fishermen and pond farmers who live very close to the coast because there are vast lands of mangrove forest.

Pick and collect forest products such as timber, including non-timber forest products in mangrove forest by various economic actors, has big potency that has direct negative affect towards degradation and deforestation. Some efforts are not adequate to protect and secure mangrove forest from coastal communities due to differences level on perception. It was found that coastal community picked and collected potential natural resources on various ecosystem mangrove forests. Thus condition leads to exploitation and destruction of mangrove forest which eventually generates into critical land and no longer productive. In this situation, it can be seen that there is high desire to maximize the profit in excessive way without considering conservation and sustainability rules and principle. Environmental 
intervention has been driven by economical aspect without considering sustainability principle. The current condition presents that forest area is damage and degraded. Some efforts are needed to be addressed to reform the current condition into optimized and sustained forest which considers dynamic and autonomous socioeconomic and environmental aspects through enhancement, strengthening and acceleration of the active participation of coastal communities.

A form of coastal communities' participation is strongly influenced by the background of their lives, including social, economic and environmental characteristics. These factors affect to the development characteristic that will be applied to the local community. It could be determined some factors that influence the participation level of coastal communities on forest rehabilitation mangrove in Muara Badak. Participation level is influenced by perception level of coastal communities, the perception of the respondents are not influenced by other variables such as education or occupation. Some efforts that can improve the participation of coastal communities can be conducted through improving coastal community perceptions regarding with the stages of mangrove forest rehabilitation. The perception improvement can be achieved through providing knowledge on mangrove forest function as well as giving the understanding on rehabilitation role. Some supports which are obtained from relevant partner are needed to be considered to provide assessment and extension function such as technical assessment, supervision, controlling, secure and conservation of mangrove forest coastal area.

Perception is also associated with awareness of coastal communities' behaviour toward uses and utilization of mangrove forests as well as conservation implementation. Perception description of coastal community on mangrove forest rehabilitation could be one of the consideration aspects for policy maker in order to improve the empowerment framework of coastal community.

High frequency of coastal community perception in Muara Badak sub district is determined by understanding framework on mangrove forest advantage and function. The result shows that workers who adequately understand about its advantage and function are $14.7 \%$, while fishermen and farmers are $18 \%$, Table 1 . The multipurpose that mangrove forest provides support for livelihoods to workers, fishermen and farmers could be factor that causes this value.

Table 1. Perception towards mangrove forest advantage and function

\begin{tabular}{|c|c|c|c|c|c|c|c|c|c|c|}
\hline \multirow[t]{2}{*}{$\begin{array}{l}\text { Occupa- } \\
\text { tion }\end{array}$} & \multicolumn{2}{|c|}{$\begin{array}{c}\text { Not } \\
\text { under- } \\
\text { stand }\end{array}$} & \multicolumn{2}{|c|}{$\begin{array}{c}\text { Less } \\
\text { understand }\end{array}$} & \multicolumn{2}{|c|}{$\begin{array}{c}\text { Adequate } \\
\text { understand }\end{array}$} & \multicolumn{2}{|c|}{$\begin{array}{l}\text { Under- } \\
\text { stand }\end{array}$} & \multicolumn{2}{|c|}{ Total } \\
\hline & $\sum$ & $\%$ & $\sum$ & $\%$ & $\sum$ & $\%$ & $\sum$ & $\%$ & $\sum$ & $\%$ \\
\hline Workers & 1 & 7 & 25 & 16.7 & 22 & 14.7 & 2 & 1.3 & 50 & 33.3 \\
\hline Fishermen & 1 & 7 & 16 & 10.7 & 27 & 18.0 & 6 & 4.0 & 50 & 33.3 \\
\hline $\begin{array}{l}\text { Pond } \\
\text { farmers }\end{array}$ & 3 & 2.0 & 8 & 5.3 & 27 & 18.0 & 12 & 8.0 & 50 & 33.3 \\
\hline Total & 5 & 3.3 & 49 & 32.7 & 76 & 50.7 & 20 & 13.3 & 150 & 100 \\
\hline
\end{tabular}

Coastal community participation on potential natural resources conservation in mangrove forest can be seen in this research. The result shows that coastal community participation is not always in line with perception result. Good perception does not guarantee active participation, vice versa. Various factors may occur, especially if personal and group's interest is looking for high profits which performed under instant manner and not support conservation and sustainable effort. Those factors can influence coastal community participation to do some positive efforts. In general, the uses and utilization towards mangrove forest natural resources of coastal community in Muara Badak sub district, especially coastal villages, is very low.

Active participation formulation strategy of coastal communities will determine the target of mangrove forest rehabilitation. Required strategy formulation is needed multidimensional analysis which accommodates all aspects involved on the development of the strategic plan and its implementation. Some aspects that need to be considered on determining the strategy includes: 1) implementation aspect of forest and land rehabilitation; 2) optimization aspect of coastal communities participation; 3) socio-economic aspects of coastal communities and sustainable environmental conservation; and 4) facilities, infrastructure, mobility and capabilities aspects of workers, fishermen and pond farmers. Data input on these aspects is obtained from the result of direct observation and interviews with the respondents.

Internal factors include the strengths and weaknesses component, while external factors include the opportunities and threats component. Those two factors are translated into a number of elements which relates to coastal community participation on the rehabilitation of mangrove forests in an integrated, effective, conserve and sustainable (see Table 2). External factor analysis is identification on external factors that includes opportunities and threats which organizes targets and objectives of the strategy to be more precise (Table 3).

Table 2. Evaluation Matrix on Internal Factor

\begin{tabular}{|c|c|c|c|c|}
\hline No & Internal factors & Weight & Rating & $\begin{array}{l}\text { Weight } \\
\text { x Rating }\end{array}$ \\
\hline & Strengths: & & & \\
\hline 1. & $\begin{array}{l}\text { High dependency of coastal } \\
\text { communities on coastal } \\
\text { resources i.e. biodiversity and } \\
\text { mangrove forest ecosystem }\end{array}$ & 0.23 & 4 & 0.92 \\
\hline 2. & $\begin{array}{l}\text { The existing of law, policy and } \\
\text { commitment of the } \\
\text { government on the mangrove } \\
\text { forest management }\end{array}$ & 0.18 & 4 & 0.72 \\
\hline 3. & $\begin{array}{l}\text { High availability of labor and } \\
\text { productive resources } \\
\text { particularly on fisheries sector }\end{array}$ & 0.12 & 4 & 0.48 \\
\hline 4. & $\begin{array}{l}\text { Availability of access, transport } \\
\text { and improvement of economic } \\
\text { changes }\end{array}$ & 0.09 & 3 & 0.27 \\
\hline 5. & $\begin{array}{l}\text { Availability of farm business } \\
\text { and shrimp cold storage } \\
\text { facilities owned by exporters }\end{array}$ & 0.07 & 2 & 0.14 \\
\hline \multicolumn{2}{|c|}{ Total Strengths: } & & & 2.53 \\
\hline
\end{tabular}


Table 3. Evaluation Matrix of External Factors

\begin{tabular}{|c|c|c|c|c|}
\hline No & External factors & Weight & Rating & $\begin{array}{c}\text { Weight } \mathrm{x} \\
\text { Rating }\end{array}$ \\
\hline & Opportunities: & & & \\
\hline 1. & $\begin{array}{l}\text { Availability of forest and land } \\
\text { rehabilitation programs and } \\
\text { activities through Community } \\
\text { Owned Nursery and Rural } \\
\text { Owned Nursery }\end{array}$ & 0.22 & 4 & 0.88 \\
\hline 2. & $\begin{array}{l}\text { Implementation of improved } \\
\text { perception and active } \\
\text { participation by strengthening } \\
\text { the development of alternative } \\
\text { economic enterprises }\end{array}$ & 0.15 & 4 & 0.60 \\
\hline 3. & $\begin{array}{l}\text { The presence of mangrove } \\
\text { forests area, critical land, } \\
\text { technical design and long- } \\
\text { term strategic plan }\end{array}$ & 0.10 & 3 & 0.30 \\
\hline Tot & Opportunities: & & & 1.78 \\
\hline & Threats: & & & \\
\hline 1. & $\begin{array}{l}\text { Pollution to coastal area, } \\
\text { coastline erosion and balance } \\
\text { environmental capacity } \\
\text { changes }\end{array}$ & 0.17 & -2 & -0.34 \\
\hline 2. & $\begin{array}{l}\text { Resource usage and utilization } \\
\text { of mangrove forest } \\
\text { ecosystems which not comply } \\
\text { with the principle of } \\
\text { environmental sustainability }\end{array}$ & 0.21 & -3 & -0.63 \\
\hline 3. & $\begin{array}{l}\text { Social conflicts between } \\
\text { coastal communities with oil } \\
\text { and gas company }\end{array}$ & 0.15 & -2 & -0.30 \\
\hline \multicolumn{2}{|c|}{ Total Threats } & & & -1.27 \\
\hline \multicolumn{2}{|c|}{ Total Opportunities and Threats } & 1.00 & & -0.51 \\
\hline
\end{tabular}

Summary value among internal factors shows that internal factors accumulation based on urgency and weight factors reaches +1.42 . The value consists of strength and weaknesses component i.e. +2.53 and -1.11 . It means that strength component is more dominant rather than weakness factors. On the other side, summary value among external value shows that external factors accumulation based on urgency and weight factors reaches +0.51 . The value consists of opportunity and threats component i.e. +2.78 and -1.27 . It means that opportunity component is more dominant rather than threats factors. The position value is in the first quadrant with ordinate 1.42:0.51 which indicates strong condition and have high opportunity (SO strategy). Strategic position is expected could improve active participation of coastal community (Figure 1).

The figure shows that effort to improve active participation of coastal community could be optimized due to high opportunity and strength despites of its threats and weaknesses. Local government through relevant agencies and local communities should be more aggressive and innovative by optimizing the active participation of coastal communities to the program and rehabilitation of mangrove forests (Rangkuti, 2006).

In order to actualize the plans, programs and activities which is developed in the strategy to improve participation of coastal communities, Analytical Hierarchy Process is applied to generate priorities alternatives on the target and objectives. This analysis was conducted in order to avoid conflicts which may occur between private and government sector including workers, fishermen, and pond farmers as an important part of the coastal communities. Partial management could reduce the quality and carrying capacity of coastal area in Mahakam estuary, Muara Badak sub district. Other aspect such as people activities which does not support sustainable program is also considered could reduce the quality and carrying capacity of coastal area. Figure 2 shows the priority hierarchy of alternative aspects and sub aspects.

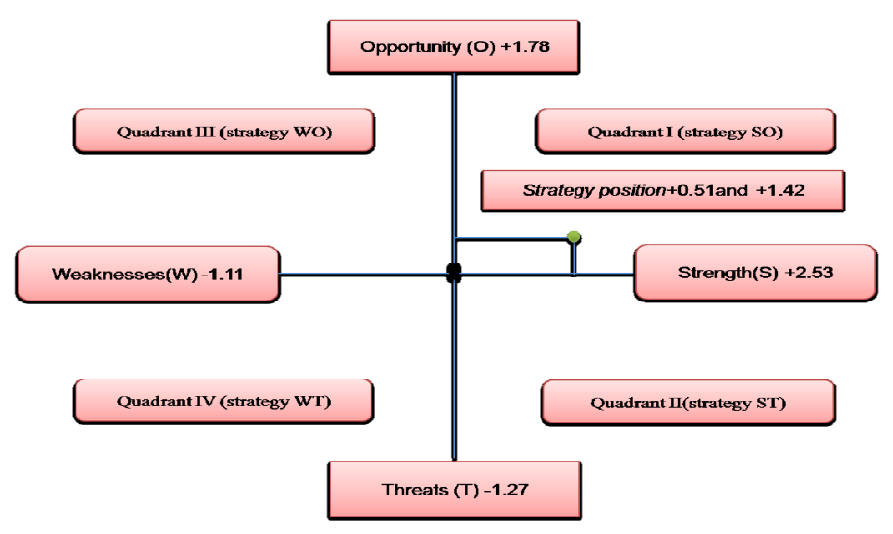

Figure 1. Strategy Position to Improve Coastal Community

Based on the above description, stakeholders on related agencies, experts, researchers from university or academician formulate four main sectors on the strategy and policies to improve active participation of coastal community on mangrove rehabilitation in Mahakam estuary, Muara Badak sub district, i.e.: 1) program development and rehabilitation of mangrove forests as a habitat for natural resources, in order to maintain the integrity of the coastal ecosystem which is supported by the development of mangrove seed gained from rural participation (A1); 2) generates positive perception on the strengthening coastal communities about the advantage and functions of mangrove forests through intensive cooperation between relevant parties to improve environment awareness in more efficient and effective participation (B1); and 3) acceleration and control upon re-vegetation and restoration of coastal areas resources which suffer from disruption and damage; rehabilitation on degraded and deforested forest and land (A2).

Utilization and economic function of mangrove forest ecosystem on different habitat or location has different value which depend on socioeconomic and bio geophysics factors. Therefore, mangrove forest ecosystem value requires thoroughly assessment both in factors which can be measured and valued directly or the one that cannot be directly measured and valued such as ecology function. The summary of alternative priority strategy and policies is listed in Table 4.

Coastal community also utilize coastal zone around in Mahakam estuary as part of mangrove forest ecosystem for fishes farming especially shrimp ponds. This situation requires mangrove forest ecosystem rehabilitation management in participative pattern which involves collective coastal community. 
Alternative priority on Strategy and Policy Aspect

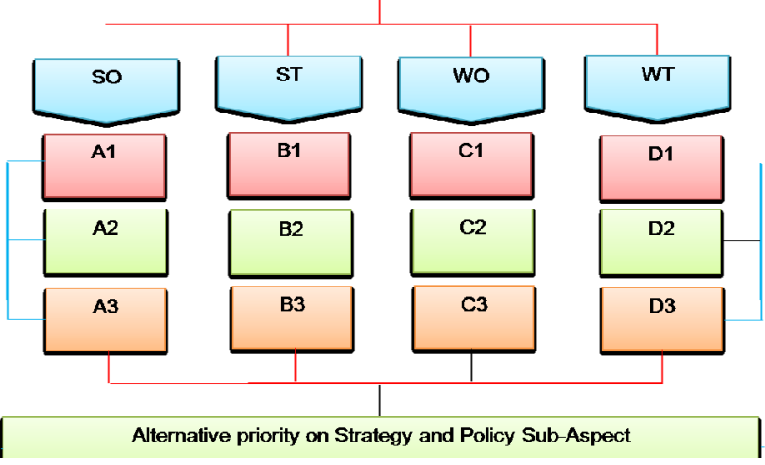

Figure 2. Alternative Priority Diagram on Aspect and Sub Aspect

Coordination in the rehabilitation framework should be carried out optimally either with relevant agencies, universities and private sector and others related parties. Close coordination among parties is needed to be taken in this present time. Efforts to improve coastal community skill can be carried out through farming biological and non-biological natural resources under conservation principle perspective. Improving entrepreneurial skill that can increase the welfare of rural coastal community and developing creative economic enterprise based on local knowledge are also needed to be addressed.

Participatory pattern consists of several components which include monitoring, dissemination and policies transparency, formal institutions, parties which involve in monitoring, controlling, conserving and securing as well as technical coaching and assistance mechanisms unit, and also sanctions to obey the law. Coaching and technical assistance programs are conducted through several activities such as training and education for coastal communities to get involved or participate in conservation program. Since the education and awareness towards mangrove forests are still relatively low, it causes limited perception on the role of mangrove forests which is very important to be preserved.

Table 4. The Summary of Alternative Priority on Mangrove Forest Rehabilitation Strategy and Policies

\begin{tabular}{|c|c|c|c|c|c|}
\hline No. & Strategies and Policies Strategy & Quadrant & Weight & Priority & Code \\
\hline 1. & $\begin{array}{l}\text { Program development and rehabilitation of mangrove forests as a habitat for } \\
\text { natural resources, in order to maintain the integrity of coastal zone ecosystem } \\
\text { which is supported by the development of rural participatory for mangrove } \\
\text { nursery }\end{array}$ & III - S0 & 0.321 & 1 & A1 \\
\hline 2. & $\begin{array}{l}\text { Acceleration and control upon re-vegetation and restoration of coastal areas } \\
\text { resources which suffer from disruption and damage; rehabilitation on degraded } \\
\text { and deforested forest and land }\end{array}$ & III - S0 & 0.114 & 3 & A2 \\
\hline 3. & $\begin{array}{l}\text { Improve the participation and develop variety of creative economic enterprise of } \\
\text { coastal communities through the use and utilization of potential resources based } \\
\text { on sustainability management }\end{array}$ & III - S0 & 0.060 & 5 & A3 \\
\hline 4. & $\begin{array}{l}\text { Generates positive perception on the strengthening coastal communities about the } \\
\text { advantage and functions of mangrove forests through intensive cooperation } \\
\text { between relevant parties to improve environment awareness in more efficient and } \\
\text { effective participation }\end{array}$ & IV - ST & 0.195 & 2 & B1 \\
\hline 5. & $\begin{array}{l}\text { Generates strong commitment and consistency of local government to support } \\
\text { coastal community social economic efforts based on preservation potential coastal } \\
\text { resource and mangrove forest ecosystem }\end{array}$ & IV - ST & 0.059 & 6 & B2 \\
\hline 6. & $\begin{array}{l}\text { Improve coastal community empowerment to get involved in active participation } \\
\text { on sustainable mangrove forest sustainability in order to provide available jobs, } \\
\text { business opportunity and build network }\end{array}$ & IV - ST & 0.054 & 8 & B3 \\
\hline 7. & $\begin{array}{l}\text { Accelerate the establishment of Guidance Unit Team and Technical Guidance Unit } \\
\text { of Mangrove Forest on Sub district level }\end{array}$ & I - WO & 0.061 & 4 & $\mathrm{C} 1$ \\
\hline 8. & $\begin{array}{l}\text { Focus and align the commitment of local government with the plan on program } \\
\text { and assisting activity for alternative business through interfering coastal } \\
\text { community i.e. workers, fishermen and pond farmers under sustainable forest } \\
\text { management principle }\end{array}$ & I - WO & 0.032 & 9 & $\mathrm{C} 2$ \\
\hline 9. & $\begin{array}{l}\text { Synergize the autonomous rural business management's program and activity } \\
\text { between non-governmental organization and rural community empowerment } \\
\text { institution through institution development, partnership cooperation and soft loan } \\
\text { provision for coastal community which supported by Corporate Social } \\
\text { Responsibility }\end{array}$ & I-WO & 0.012 & 12 & $\mathrm{C} 3$ \\
\hline 10. & $\begin{array}{l}\text { Acceleration and improvement the quality of people resources, facilities, } \\
\text { infrastructure, training, skills and appropriate technology implementation to } \\
\text { support coastal communities' business program }\end{array}$ & II - WT & 0.059 & 7 & D1 \\
\hline 11. & $\begin{array}{l}\text { Optimization of local government policies with coastal community on controlling, } \\
\text { monitoring, conserving and securing mangrove forest using persuasive and } \\
\text { preventive approach }\end{array}$ & II - WT & 0.018 & 10 & D2 \\
\hline 12. & $\begin{array}{l}\text { Affirmation action by law enforcement to overcome the expansion of new ponds, } \\
\text { forest encroachment and illegal logging which endangers the preservation of } \\
\text { potential coastal resources and coastal mangrove forest ecosystems }\end{array}$ & II-WT & 0.016 & 11 & D3 \\
\hline
\end{tabular}




\section{Conclusions}

Several conclusion points that can be generated based on the analysis result are as follows: Participation difference level is categorized on two criterions: very low and low. Very low criterion reaches up to $81.3 \%$ with 122 respondents, while low criterion up to $15.3 \%$ with 23 respondents. Factor which affects the active participation of coastal community on mangrove forest rehabilitation is low level. Effective reformation on program and activity development for mangrove forest rehabilitation as natural resources is needed to be applied in order to improve active participation of coastal community. New model formulation which is presented by rural participatory for mangrove nursery is expected to support the integrity of coastal zone ecosystem.

\section{REFERENCES}

[1] Allen, G. P., and John L. C. Chambers. 1998. Sedimentation in the Modern Delta and Miocene Mahakam Delta, Indonesian Petroleum Association, Jakarta.

[2] Asikin, A,N., S. Hutabarat, Y. S. Darmanto and S. B. Prayitno. 2012 Strategy of quality improvement of pond shrimp post harvest management (Penaeus monodon F.) in Mahakam delta (case study). Int. J. Sci. Eng., 3 (2): 15-20.

[3] Bengen, D. G., R.R. Rini Budi Sayekti, N. Makinuddin, P. Santoso Das'at and T. Gunawan. 2003. Realities and Issues - issues of Resources and Environment in Mahakam Delta, Rapid Appraisal, Coastal Projects PKSPL - IPB, Bogor; Bapedalda Kutai Kartanegararegency; Coastal Project in East Kalimantan ; USAID; Total Fina Elf E \& P Indonesia, The Nature Conservancy, Bogor, Indonesia. $10 \mathrm{pp}$.

[4] Bourgeois, Robin, Anne Gouyon, F. Jesus, P. Levang, W. Langeraar, F. Rahmadani, E. Sudiono and B. Sulistiadi. 2002. A Socio Economic and Institutional Analysis of Mahakam Delta Stakeholders (Final Report, TOTAL), Jakarta. 107 pp.

[5] Clark and John. 1974. Coastal Ecosystems, The Conservation Foundation, Washington D.C. 178 pp.

[6] Dutrieux and Eric. 2001. The Mahakam Delta Environment, From the 80s up to now: A Synthesis of a 15-Years Investigation, (Eds, Tridoyo Kusumastanto, Dietriech G. Bengen, Bambang Widigdo and Imam Soeseno), In Optimizing Development and Environmental Issues at Coastal Area: Problem and Solution for
Sustainable of Mahakam Delta, Jakarta, Indonesia, PertaminaTotalFinaElf E\&P Indonesia, PKSPL-IPB, Department of Marine Affairs and Fisheries, pp. 63 - 65.

[7] Hopley and David. 1999. Assessment of the Environmental Status and Prospect of Aquaculture in the Mahakam Delta. Total Indonesie, Balikpapan.

[8] Mayulu, 2012. Optimalized of palm oil plantation and by product's carrying capacity for ruminants feedstuff by feed processing technology. (Approach of SWOT and Analytic Hierarchy Process). Jurnal Teknologi Pertanian 7: 60 - 72.

[9] Murti, H and Cahya. 2000. Estuary Conservation Area Management Plan With Spatial and Zoning Approach (Case Study Segara Anakan, Cilacap District, Central Java), Dissertation, Graduate Program - Center for Environmental Studies, Bogor Agricultural University, Bogor, 259 pp.

[10] Rangkuti, F. 2008. SWOT Analysis of Exploring Business Cases (The Reorientation of Strategic Planning Concept for Dealing with $21^{\text {st }}$ Century). $15^{\text {th }}$ Edition. PT. Gramedia Pustaka Utama Publications, Jakarta.

[11] Saaty, R. L. 1993. Decision Making for Leaders (Analytic Hierarchy Process for Complex Decision Making). Management No. 134 PT. Pustaka Binaman Pressindo, Jakarta. (Translated by Liana Setiono).

[12] Sidik, A.S. 2008. The Changes of Mangrove Ecosystem in Mahakam Delta,Indonesia: A Complex Sosial-Envinronmental Pattern of Lingkages in Resources Utilization. Paper Presented at The South China Sea Conference. Sustaining OceanProductivities, Maritime Communities and the Climate, Kuantan. 1-20.

[13] Syamsuri, A. 2001. Potencies and Problems in Mahakam Delta, (Eds, T. Kusumastanto, G. Dietriech Bengen, B. Widigdo and Imam Soeseno), In International Workshop for Optimizing Development and EnvironmentalIssues at Coastal Area: Solution for Sustainable Management of Mahakam Delta., Jakarta, Indonesia, PertaminaTOTALFINAELF E\&P Indonesie, PKSPL-IPB, Department of Marine Affairs and Fisheries, pp. 27 - 30.

[14] Voss and Frithjof. 1983. East Kalimantan Transmigration Area Development Project PTA 46/ATA 140, TAD-Report No. 9 Natural Resources Inventory, Department of Transmigration, Republic of Indonesia; Federal Republic of Germany, Samarinda, Indonesia. $199 \mathrm{pp}$.

[15] Wibowo, Prianto, C. E. Nirarita, S. Susanti, D. Padmawinata, Kusmarini, M. Syarif, Y. Hendriani, Kusniangsih and L. Sinulingga. 1996. Indonesian Wetland Ecosystems: A Guide for Teachers and Academician Practitioners, Wetlands International Indonesia Programme, Bogor. 